\title{
Non-toxic melanin production inhibitors from Garcinia livingstonei \\ (Clusiaceae)
}

Dulcie A Mulholland ${ }^{\mathrm{a}, \mathrm{f}, *}$, Elizabeth M Mwangi ${ }^{\mathrm{b}, \mathrm{f}}, \mathrm{Ncoza}_{\mathrm{C}}$ Dlova $^{\mathrm{c}}$, Nick Plant ${ }^{\mathrm{d}}$, Neil R Crouch ${ }^{\mathrm{e}, \mathrm{f}}$ and Phillip H Coombes $^{f}$

${ }^{a}$ Natural Products Research Group, Department of Chemistry, Faculty of Engineering and Physical Sciences, University of Surrey, Guildford, Surrey, GU2 7XH, United Kingdom

${ }^{\mathrm{b}}$ Department of Chemistry, Egerton University, P.O. Box 536, Njoro 20107, Kenya

${ }^{c}$ Department of Dermatology, Nelson R Mandela School of Medicine, Private Bag X 7, Congella, Durban 4013, Durban, South Africa

${ }^{\mathrm{d}}$ Centre for Toxicology, Faculty of Health and Medical Sciences, University of Surrey, Guildford, Surrey, GU2 7XH, United Kingdom

${ }^{\mathrm{e}}$ Ethnobotany Unit, South African National Biodiversity Institute, PO Box 52099, Berea Road 4007, South Africa

${ }^{\mathrm{f}}$ School of Chemistry and Physics, University of KwaZulu-Natal, Westville Campus, Private Bag X54001, Durban, 4001 South Africa

*Corresponding Author. Tel: +44(0)1483686827. Email address: $\underline{\text { d.mulholland@ surrey.ac.uk }}$ 


\section{ABSTRACT}

Ethnopharmacological relevance: The stem bark of Garcinia livingstonei is used traditionally as a skin lightening agent.

Aim of the study: To isolate and identify compounds responsible for the observed skin lightening activity of Garcinia livingstonei and to evaluate their cytotoxicity.

Materials and Methods: Constituents of the stem bark and fruits of Garcinia livingstonei were isolated using chromatographic techniques and structures were determined using 1D and 2D NMR and MS analysis. MeWo cells were used to evaluate the cytotoxicity and impact on melanin levels of extracts and compounds isolated, in vitro.

Results: Twelve known compounds, morelloflavone (1), morelloflavone-7'-sulphate (2), guttiferone A (3), sargaol (4), isojacareubin (5), 6-deoxyisojacareubin (6) and in addition to the common triterpenoids, betulin, betulin aldehyde, lupeol, lupenone, euphol and stigmasterol were isolated in this investigation. Morelloflavone, morelloflavone-7"-sulphate and sargaol, were found to be considerably less cytotoxic and more effective as skin lightening agents than hydroquinone.

Conclusions: A range of compounds was isolated from the stem bark and fruit of Garcinia livingstonei. Although the bark extract contained the cytotoxic guttiferone A, it was found to be less toxic than hydroquinone, and morelloflavone, the 7"-sulphate derivative and sargaol show potential for development as depigmentation/skin lightening agents.

Keywords: Garcinia livingstonei; Clusiaceae; melanin production inhibitor; MeWo cells; skin lightening agents

Chemical compounds used in this article.

Morelloflavone (PubChem CID 5464454); Guttiferone A (PubChem CID 5352090) 


\section{Introduction}

Garcinia livingstonei T. Anderson (syn. G. angolensis Vesque)(Clusiaceae) is found throughout tropical Africa, where it occurs as a distinctive small to medium sized (2-10 m) evergreen tree in low altitude riverine fringes and open woodlands (Palgrave, 2002). It is known variously in South Africa as the African or Lowveld Mangosteen, and umPhimbi, isiHlumanye or uGobandlovu (isiZulu) (Pooley, 1993; Hutchings et al., 1996). The wood is used as a general purpose timber, while the flesh of the pinkish orange fruit is edible, with a refreshing acid-sweet taste, and can also be fermented to prepare a pleasant alcoholic beverage (Palgrave, 2002).

The powdered root is used as an aphrodisiac in the treatment of impotence (Arnold and Gulumian, 1984), for abdominal pains during pregnancy (Samuelsson et al., 1992), and as an aid in childbirth (Yu, 1982), while steam from a decoction of the dried leaves is used to treat watering eyes (Arnold and Gulumian, 1984). Coughs, fevers and parasitic diseases are treated with infusions of the fruits and stems (Iwu, 1993).

Previous investigations of this species have resulted in the isolation of a variety of bioactive oxygenated aromatic compounds. A series of novel prenylated xanthones was isolated from Garcinia livingstonei which showed fungiostatic activity against Cladosporium cucumerinum comparable to that of miconazole, and inhibited SW 480 human colon carcinoma cell growth at levels similar to that of 5-fluorouracil (Sordat-Diserens et al., 1992a). Sordat-Diserens et al. (1992b) isolated the xanthone dimer garcilivin A, which has since been shown to display trypanosomal activity against T. brucei brucei (Mbwambo et al., 2006). Bioassay-guided fractionation of the fruit has yielded the HIV-inhibitory tetraprenylated benzophenone guttiferone A (3) (Gustafson et al., 1992), and the biflavanoid ent-naringeninyl-(I-3 $\alpha, \mathrm{II}-8)-4$ '-O-methylnaringenin which is moderately active against a Ghanaian CQS strain of $P$. falciparum (Mbwambo et al., 2006).

Several tree species are used traditionally on the eastern seaboard of South Africa for the treatment of skin diseases and cosmetic purposes, such as for skin lightening, often under the Xhosa and Zulu name umemezi (Earle, 1976; Khan, 1996; Cocks \& Dold, 2004; Momtaz et al., 2008). Although a highly valued ethnomedicinal species (Hutchings et al., 1996), dermatological uses for Garcinia livingstonei have not earlier been documented either locally, or elsewhere in its extensive tropical 
African range. Only recently has its application in skin treatment been reported through a personal communication to one of us (NCD) in her capacity as a dermatologist. Clinical observations (Dlova, 2002, unpublished results) have revealed that a water slurry of the powdered stem bark is an effective facial sunscreen and/or skin lightener. A literature search indicated that other Garcinia species such as Garcinia indica Choisy (Jain \& DeFilipps, 1991) are used to treat skin diseases, with two taxa, the African Garcinia kola Heckel and the Asian G. subelliptica Merr. reported to yield tyrosinase inhibitors, from leaves and fruit respectively (Masuda et al., 2005; Okunji et al., 2007).

As no previous studies have focused on this aspect of the use of G. livingstonei, the current work was carried out with the aim of isolating compounds for screening for possible application in skinlightening preparations.

Disorders of hyperpigmentation are seen in all skin types; however, they are encountered more frequently in skin of color (Kanthraj, 2010). While no single therapy has been shown to be superior or to be of benefit to all patients, sometimes combination therapy is recommended to maximize the management of complex cases (Sheth \& Pandya, 2011). The main goal of treatment is to decrease the hyperpigmentation with minimal side effects. A range of topical agents are available to treat hyperpigmentation and act at different levels of the melanogenesis pathway (Kanthraj, 2010; Sheth \& Pandya, 2011). The most common synthetic pharmacologic agents used are hydroquinone, corticosteroids, and mercurials (Olumide et al., 2008). The long-term use of these products may cause undesirable cutaneous or systemic side effects (Findlay et al., 1975; Findlay \& de Beer, 1980; Olumide et al., 2008).

$p$-Hydroquinone (1,4-dihydroxybenzene) was one of the earliest products used for the treatment of hyperpigmentation and remains the standard against which other treatments for hyperpigmentation are measured. (Draelos, 2007; Sheth \& Pandya, 2011). However, its use has been associated with various side effects, which include irritant contact dermatitis and exogenous ochronosis (Findlay \& de Beer, 1980; Hardwick et al., 1989; Olumide et al., 2008). In 1975, Findlay and co-workers reported ochronosis amongst black South African women after prolonged use of skin lightening creams containing $p$-hydroquinone, which inhibits tyrosinase and prevents the conversion of tyrosine to dihydroxyphenylalanine, a precursor of melanin. Tyrosinase is, accordingly, a potential target in the search for a medically acceptable skin lightening agent from natural sources. This subject has been the focus of a recent review (Smit et al., 2009). 
Given the problems related to hydroquinone use, there exists a need for the identification of novel agents that can be used as skin lightening products, either for cosmetic or clinical use. In this work we examine the properties of compounds isolated from Garcinia livingstonei, measuring both their ability to both alter melanin levels in human melanoma cells, and their relative cytotoxicity.

\section{Experimental section}

\subsection{Plant material}

Stembark of Garcinia livingstonei T. Anderson was collected in Zululand, KwaZulu-Natal Province, South Africa, in June 2002, and fruits were collected on the Howard College Campus of the University of KwaZulu-Natal in January 2004. Plant material was identified by Professor Neil Crouch and vouchers for bark (N. Crouch 942) and fruit (N. Crouch 1137) lodged at the KwaZuluNatal Herbarium (NH) in Durban.

\subsection{Isolation of Compounds}

The stem bark was air-dried at room temperature and milled, while the fresh fruits were first peeled and the nut-like kernels separated from the surrounding fruit flesh. The dry powdered stem bark $(0.65 \mathrm{~kg})$ was successively extracted with dichloromethane, ethyl acetate and methanol for twentyfour hours each, using a Soxhlet apparatus, and the solvents concentrated in vacuo to yield 14.6, 18.7 and $62.2 \mathrm{~g}$ of extract, respectively. ${ }^{1} \mathrm{H}$ NMR and tlc analysis showed that the ethyl acetate and methanol extracts of the stem bark were very similar, and they were combined. Fresh seed kernels $(1.2 \mathrm{~kg})$, obtained as described above, were successively extracted in similar fashion with hexane, dichloromethane, ethyl acetate and methanol, yielding 38.9, 2.2, 6.4 and $50.0 \mathrm{~g}$ of extract, respectively. The fresh fruit peel (1 kg wet mass) was soaked in methanol overnight, filtered, and the filtrate concentrated in vacuo to give a suspension, which was extracted with ethyl acetate and concentrated in vacuo, yielding $18.8 \mathrm{~g}$ of extract.

Repeated separation by gravity column normal phase (Merck $9385 \mathrm{Si}$ gel) and size exclusion (Sephadex LH-20) chromatography, and semi-preparative scale tlc (Merck 05554 aluminium-backed tlc plates) was undertaken using hexane:dichloromethane:ethyl acetate:acetone:methanol solvent mixtures. The dichloromethane extract of the stem bark yielded betulin, $(2.5 \mathrm{~g})$, betulin aldehyde (5 $\mathrm{mg})$, lupeol (5 mg), lupenone (5 mg), euphol (50 mg) and stigmasterol (120 mg). The combined ethyl acetate/methanol extract of the stem bark yielded morelloflavone (1) (20 mg) and morelloflavone-7"'-sulphate (2) (20 mg). Guttiferone A (3) (5 mg) was isolated from the fruit peel 
extract. The hexane extract of the fruit kernels yielded sargaol (4) (50 mg) and isojacareubin (5) (5 $\mathrm{mg}$ ) and 6-deoxyisojacareubin (6) (5 mg) were isolated from the dichloromethane extract.

\subsection{Identification of Compounds isolated.}

NMR anaylsis was performed on a Bruker $400 \mathrm{MHz}$ NMR spectrophotometer and spectra were determined in $\mathrm{CDCl}_{3}$ or $\mathrm{CD}_{3} \mathrm{OD}$. HRMS were recorded on a Finnigan MAT 95 XP high resolution Double Focussing MS at the University of Surrey. Structures of compounds isolated were confirmed by comparison of NMR and MS data against literature values as referenced in Section 3.

\section{$2.4 \quad$ In-vitro screening of compounds isolated}

A human granular fibroblast cell line derived from malignant melanoma was used in all in vitro assays (MeWo; ECACC No: 93082609) and was purchased from ECACC (Porton Down, UK). Cells were grown in EMEM supplemented with $2 \mathrm{mM}$ glutamine, $1 \%$ non-essential amino acids, $10 \%$ foetal bovine serum and 100U/ml penicillin, $100 \mu \mathrm{g} / \mathrm{ml}$ streptomycin. All cell culture medium and supplements were purchased from Invitrogen (Paisley, UK). MeWo cells were seeded into 96-well plates (Nunc International, Leicestershire, UK) at a concentration of 10,000 cells/well and incubated at $37^{\circ} \mathrm{C}$ for $48 \mathrm{hrs}$ in a humidified container for attachment. Chemicals/crude extracts or vehicle (0.1\% DMSO) was then added to the wells at the indicated concentrations and cells incubated for a further forty-eight hours. Following exposure, medium was collected and cytotoxicity determined by LDH-leakage using the cytotoxicity detection kit (Roche, Lewes, Sussex, UK), as per the manufacturer's instructions. For evaluation of melanin content, cells were washed with PBS, lysed with $1 \mathrm{~N} \mathrm{NaOH}$ and centrifuged to remove cellular debris. The melanin content of the supernatant was then determined by optical density at $405 \mathrm{~nm}$ (Takiwaki et al., 2004).

\section{Results and Discussion}

Twelve known compounds, morelloflavone (1) (Li et al., 2002), morelloflavone-7"-sulphate (2) (Li et al., 2002), guttiferone A (3) (Gustafson et al., 1992), sargaol (2-geranyl-6-hydroxy-2,8-dimethylchromene) (4) (Numuta et al., 1992; Voutquenne et al., 1999), isojacareubin (5) (Helesbeux et al., 2004), 6-deoxyisojacareubin (6) (Ishiguro et al., 1993) and the common triterpenoids, betulin, betulin aldehyde, lupeol, lupenone, euphol and stigmasterol were isolated in this investigation The structures of the isolated compounds were established using NMR spectroscopy and mass spectrometry and by comparison against literature data as referenced above. 
In addition to its HIV-inhibitory activity (Gustafson et al., 1992), guttiferone A (3) has also been shown to be a potent inhibitor of cholinesterase (Lenta et al., 2007) and glutathione transferase enzymes (Muleya et al., 2008), as well as exhibiting antioxidant (Ngouela et al., 2006), leishmanicidal (Lenta et al., 2007), antiplasmodial (Ngouela et al., 2006), trypanocidal (Abe et al., 2004), and cytotoxic (Williams et al., 2003) effects. The activity of morelloflavone (1) as an antiinflammatory (Gil et al., 1997; Castardo et al., 2008) and antioxidant (Sanz et al., 1994; Deachathai et al., 2005; Hutadilok-Towatana et al., 2007) are well-documented; it has also been found to be a potent tyrosinase inhibitor (Masuda et al., 2005), anti-HIV-1 (Lin et al., 1997), and anti-bacterial (Verdi et al., 2004) agent, and to have antimalarial (Ngouamegne et al., 2008) and analgesic (Luzzi et al., 1997) properties. Isojacareubin (5) is known for its activity as an anticoagulant (Wu et al., 1998), and 6-deoxyisojacareubin (6) for its antifungal (Morel et al., 2002) and antibacterial (Kuete et al., 2007) properties, while sargaol (4) shows marked activity as an antioxidant (Nahas et al., 2007).

Morelloflavone (1), morelloflavone-7"-sulphate (2), guttiferone A (3), and sargaol (4) together with the ethyl acetate and methanol extracts of G. livingstonei stem bark (crude extracts 39b and 39c respectively), and the fruit peel extract, were selected for further in vitro analysis. MeWo cells, a human malignant melanoma cell line, were selected to investigate the action of these compounds and extracts in vitro, both in terms of impact on melanin levels and overall cytotoxicity. The melanin content of the melanocytes was determined after dosing these cells with known concentrations of the test extracts/compounds, whereas the cytotoxicity assay was based on the measurement of lactate dehydrogenase $(\mathrm{LDH})$ released from the cytosol of damaged cells into the culture medium: Full details of the procedures used are given in the Experimental section.

Prior to examining the derived compounds and extracts, the response of MeWo cells to the classical pro-oxidant and skin-lightening agent hydroquinone was examined. As can be seen from figure 2, hydroquinone was able to elicit a dose-dependent decrease in melanin content of the cells, with an $\mathrm{EC}_{50}=87 \pm 1.3 \mu \mathrm{M}$. This effect on melanin content was accompanied by dose-dependent cytotoxicity, with an $\mathrm{IC}_{50}=45 \pm 5.4 \mu \mathrm{M}$.

Following characterization of the response of MeWo cells to hydroquinone, we next examined the effect of the $25 \mu \mathrm{M}$ for pure chemicals and $100 \mathrm{mg} / \mathrm{mL}$ for crude extracts on both melanin content and cytotoxicity (Figure 3). The fruit peel extract was extremely cytotoxic, leading to complete cell death within 48 hours and compromising the LDH readings. In addition, the crude extracts $\mathbf{3 9 b}$ and 39c were both darkly coloured and their melanin readings were thus also compromised; these results 
will not be discussed further. As previously observed by Williams and colleagues, guttiferone A was shown to be cytotoxic, with $25 \mu \mathrm{M}$ causing approximately $80 \%$ cell death, a value that is consistent with the reported $\mathrm{IC}_{50}$ value of approximately $1 \mu \mathrm{M}$ (Williams et al. 2003). This was the most cytotoxic pure chemical examined, with $25 \mu \mathrm{M}$ exposures of morrelloflavone, morelloflavone -7"sulphate and sargaol only causing between $10-20 \%$ cell death (Figure $3 a$ ).

In addition, all compounds were able to decrease the melanin content of the cells (Figure $3 \mathrm{~b}$ ), although to differing extents. Again, guttiferone A produced the largest decrease, but this interesting activity was offset by the large cytotoxic effect observed at the same dose. Morelloflavone, morelloflavone -7"-sulphate and sargaol all caused significant decreases in melanin content (approximately $60 \%$ of control; Figure 3), while causing less than $20 \%$ cell death at $25 \mu \mathrm{M}$. Accordingly, these compounds were selected for a more complete concentration-response examination. Figure 4 shows concentration-response curves for each compound ( $1 \mu \mathrm{M}$ to $100 \mu \mathrm{M})$, with both cytotoxicity (LDH) and melanin content measured. Morelloflavone, morelloflavone-7"sulphate and sargaol all elicited a dose-dependent effect on cytotoxicity and melanin content (Figure 4a, b, c, respectively). All three compounds elicited a concentration-dependent decrease in melanin content and cytotoxicity in MeWo cells, with morelloflavone-7"-sulphate having the most promising profile. Figure $4 \mathrm{~b}$ shows a clear separation of the curves for cytotoxicity $\left(\mathrm{IC}_{50}=41.8 \pm 2.5 \mu \mathrm{M}\right)$ and melanin content $\left(\mathrm{EC}_{50}=8.6 \pm 1.3 \mu \mathrm{M}\right)$, suggesting that this compound has the most favourable balance of maximal pharmacological effect with minimal toxicological liability. It should be noted, however, that of the three compounds tested morelloflavone-7"-sulphate also elicits the smallest absolute change in melanin content, being $74 \%$ of control, compared to $13 \%$ for sargaol; the current dose range was insufficient to determine a robust maximal effect for morelloflavone, but it is expected to be in excess of $60 \%$.

\section{Conclusion}

Morelloflavone (1), morelloflavone-7"-sulphate (2), guttiferone A (3), and sargaol (4) are all more effective in reducing melanin content of MeWo human melanoma cells than hydroquinone. In addition, morelloflavone, morelloflavone-7"-sulphate , and sargaol are less cytotoxic. Although morelloflavone, isolated from Japanese material of Garcinia subelliptica has previously been shown to possess potent tyrosinase inhibitory activity (Masuda et al., 2005), the current investigation revealed that morelloflavone-7"-sulphate 7 possessed the best separation between reduction in melanin and induction of cell death. 
In conclusion, preliminary results show that morelloflavone, morelloflavone-7"'-sulphate and sargaol are highly effective melanin production inhibitors. When tested in the human melanoma cell line MeWo, they inhibit melanogenesis to a greater extent than hydroquinone, whilst causing less cytotoxicity. As such, these compounds represent good candidates for further development of novel skin lightening agents to be used in the cosmetic and clinical arenas.

\section{Acknowledgements}

Mr Bret Parel, Mr Dilip Jagjivan and the late Mr Ernest Makhaza are thanked for their technical assistance. The staffs of both the Mary Gunn Library (SANBI) and the W.J. Talbot Library (UCT) are thanked for facilitating access to literature.

\section{References}

Abe, F., Nagafuji, S., Okabe, H., Akahane, H., Estrada-Muniz, E., Huerta-Reyes, M., Reyes-Chilpa, R., 2004. Trypanocidal constituents in plants. 3. Leaves of Garcinia intermedia and heartwood of Calophyllum brasiliense. Biological and Pharmaceutical Bulletin 27, 141-143.

Arnold, H.J., Gulumian, M., 1984. Pharmacopoeia of traditional medicine in Venda. Journal of Ethnopharmacology 12, 35-74.

Castardo, J.C., Prudente, A.S., Ferreira, J., Guimaraes, C.L., Delle Monache, F., Cechinel Filho, V., Otuki, M. F., Cabrini, D.A., 2008. Anti-inflammatory effects of hydroalcoholic extract and two biflavonoids from Garcinia gardneriana leaves in mouse paw oedema. Journal of Ethnopharmacology 118, 405-411.

Cocks, M., Dold, A., 2004. The informal trade of Cassipourea flanaganii as a cosmetic in South Africa. In: T. Sunderland \& O. Ndoye (eds.), Forest Products, Livelihoods and Conservation: Case Studies of Non-Timber Forest Product Systems, Vol. 2 - Africa, Centre for International Forestry Research, Jakarta, pp. 73-90.

Deachathai, S., Mahabusarakam, W., Phongpaichit, S., Taylor, W.C., 2005. Phenolic compounds from the fruit of Garcinia dulcis. Phytochemistry 66, 2368-2375.

Draelos, Z.D., 2007. Skin lightening preparations and the hydroquinone controversy. Dermatologic Therapy 20, 308-313.

Earle, R., 1976. Can the Nubian change his skin or the leopard his spots? African Wildlife 30(6), 8. 
Findlay, G.H., de Beer, H.A., 1980. Chronic hydroquinone poisoning of the skin from skin-lightening cosmetics. A South African epidemic of ochronosis of the face in dark-skinned individuals. South African Medical Journal 57, 187-190.

Findlay, G.H., Morrison, J.G., Simson, I.W., 1975. Exogenous ochronosis and pigmented colloid milium from hydroquinone bleaching creams. British Journal of Dermatology 93, 613-622.

Gustafson, K.R., Blunt, J.W., Munroe, H.G., Fuller, R.W., McKee, T.C., Cardellina II, J.H., McMahon, J.B., Cragg, G.M., Boyd, M.R., 1992. The guttiferones, HIV-inhibitory benzophenones from Symphonia globulifera, Garcinia livingstonei, Garcinia ovatifolia and Clusia rosea. Tetrahedron 48, 10093-10102.

Gil, B., Sanz, M.J., Carmen Terencio, M., Gunasegaran, R., Paya, M., Alcaraz, M.J., 1997. Morelloflavone, a novel biflavonoid inhibitor of human secretory phospholipase A2 with anti-inflammatory activity. Biochemical Pharmacology 53, 733-740.

Hardwick, N., Van Gelder, L.W., Van der Merwe, C.A., Van der Merwe, M.P., 1989. Exogenous ochronosis: an epidemiological study. British Journal of Dermatology 120, 229-238.

Helesbeux, J.-J., Duval, O., Dartiguelongue, C., Seraphin, D., Oger, J.-M., Richomme, P., 2004. Synthesis of 2-hydroxy-3-methylbut-3-enyl substituted coumarins and xanthones as natural products. Application of the Schenck ene reaction of singlet oxygen with ortho-prenylphenol precursors. Tetrahedron 60, 2293-2300.

Hutadilok-Towatana, N., Kongkachuay, S., Mahabusarakam, W., 2007. Inhibition of human lipoprotein oxidation by morelloflavone and camboginol from Garcinia dulcis. Natural Product Research, Part B: Bioactive Natural Products 21, 655-662.

Hutchings, A., Scott, A.H., Lewis, G., Cunningham, A.B., 1996. Zulu Medicinal Plants - an Inventory. University of Natal Press, Pietermaritzburg, p 204.

Ishiguro, K., Nagata, S., Fukumoto, H., Yamaki, M., Isoi, K., Oyama, Y., 1993. Part 7. An isopentenylated flavonol from Hypericum japonicum. Phytochemistry 32, 1583-1585.

Iwu, M.M., 1993. Handbook of African Medicinal Plants. CRC Press, Florida.

Jain, S.K., DeFilipps, R.A., 1991. Medicinal plants of India. Vol. 1. Reference Publications, Michingan, USA. Kanthraj G.R., 2010. Skin-lightening agents: New chemical and plant extracts-ongoing search for the holy grail! Indian Journal of Dermatology, Venereology, and Leprology 76, 3-6. 
Khan, F., 1996. Skin lightening in South Africa. A report on the use of skin lightening preparations, with specific reference to the extent and nature of the use of indigenous plant materials in Cape Town. Unpublished EAU Report No. 01/96/10, University of Cape Town, South Africa.

Kuete, V., Nguemeving, J.R., Beng, V.P., Azebaze, A.G.B., Etoa, F-X., Meyer, M., Bodo, B., Nkengfack, A.E., 2007. Antimicrobial activity of the methanolic extracts and compounds from Vismia laurentii De Wild (Guttiferae). Journal of Ethnopharmacology 109, 372-379.

Lenta, B.N., Vonthron-Senecheau, C., Weniger, B., Devkota, K.P., Ngoupayo, J., Kaiser, M., Naz, Q., Choudhary, M.I., Tsamo, E., Sewald, N., 2007. Leishmanicidal and cholinesterase inhibiting activities of phenolic compounds from Allanblackia monticola and Symphonia globulifera. Molecules 12, 1548-1557.

Li, X.-C., Joshi, S.A., Tan, B., El-Sohly, H.N., Walker, L.A., Zjawiony, J.K., Ferreira, D., 2002. Absolute configuration, conformation and chiral properties of flavanone-( $3 \rightarrow 8$ ")-flavone biflavonoids from Rheedia acuminata. Tetrahedron 58, 8709-8717.

Lin, Y-M., Anderson, H., Flavin, M.T., Pai, Y-H. S., Greenwood, E.M., Pengsuparp, T., Pezzuto, J.M., Schinazi, R.F., Hughes, S.H., Chen, F-C., 1997. In vitro anti-HIV activity of biflavanoids isolated from Rhus succedanea and Garcinia multiflora. Journal of Natural Products 60, 884-888.

Luzzi, R., Guimaraes, C.L., Verdi, L.G., Simionatto, E.L., Delle Monache, F., Yunes, R.A., Floriani, A.E.O., Cechinel-Filho, V., 1997. Isolation of biflavonoids with analgesic activity from Rheedia gardneriana leaves. Phytomedicine 4, 141-144.

Masuda, T., Yamashita, D., Takeda, Y., Yonemori, S., 2005. Screening for tyrosinase inhibitors among extracts of seashore plants and identification of potent inhibitors from Garcinia subelliptica. Bioscience, Biotechnology, and Biochemistry 69, 197-201.

Mbwambo, Z.H., Kapingu, M.C., Moshi, M.J., Machumi, F., Apers, S., Cos, P., Ferreira, D., Marais, J.P.J., Van den Berghe, D., Maes, L., Vlietinck, A., Pieters, L., 2006. Antiparasitic activity of some xanthones and biflavonoids from the root bark of Garcinia livingstonei. Journal of Natural Products 69, 369-372.

Momtaz, S., Mapunya, B.M., Houghton, P.J., Edgerly, C., Hussein, A., Naidoo, S., Lall, N., 2008. Tyrosinase inhibition by extracts and constituents of Sideroxylon inerme L. stem bark, used in South Africa for skin lightening. Journal of Ethnopharmacology 119, 507-512.

Morel, C., Seraphin, D., Teyrouz, A., Larcher, G., Bouchara, J-P., Litaudon, M., Richomme, P., Bruneton, J., 2002. New and antifungal xanthones from Calophyllum caledonicum. Planta Medica 68, 41-44. 
Muleya, V., Hayeshi, R., Ranson, H., Abegaz, B., Bezabih, M-T., Robert, M., Ngadjui, B.T., Ngandeu, F., Mukanganyama, S., 2008. Modulation of Anopheles gambiae Epsilon glutathione transferase activity by plant natural products in vitro. Journal of Enzyme Inhibition and Medicinal Chemistry 23, 391-399.

Nahas, R., Abatis, D., Anagnostopoulou, M.A., Kefalas, P., Vagias, C., Roussis, V., 2007. Radicalscavenging activity of Aegean Sea marine algae. Food Chemistry 102, 577-581.

Ngouamegne, E.T., Fongang, R.S., Ngouela, S., Boyom, F.F., Rohmer, M., Tsamo, E., Gut, J., Rosenthal, P.J., 2008. Endodesmiadiol, a friedelane triterpenoid, and other antiplasmodial compounds from Endodesmia calophylloides. Chemical \& Pharmaceutical Bulletin 56, 374-377.

Ngouela, S., Lenta, B.N., Noungoue, D.T., Ngoupayo, J., Boyom, F.F., Tsamo, E., Gut, J., Rosenthal, P.J., Connolly, J.D., 2006. Anti-plasmodial and antioxidant activities of constituents of the seed shells of Symphonia globulifera Linn f. Phytochemistry 67, 302-306.

Numuta, A., Kanbara, S., Takanishi, C., Fujiki, R., Yoneda, M., Usami, Y., Fujita, E., 1992. A cytotoxic principle of the brown alga Sargassum tortile and structures of chromenes. Phytochemistry 31, 1209-1213.

Okunji, C., Komarnytsky, S., Fear, G., Poulev, A., Ribnicky, D.M., Awachie, P.I., Ito, Y., Raskin, I. 2007. Preparative isolation and identification of tyrosinase inhibitors from the seeds of Garcinia kola by high-speed counter-current chromatography. Journal of Chromatography A 1151, 45-50.

Olumide, Y.M., Altraide, D., Mohammed, T., Ahamefule, N., Ayanlowo, S., Onyekonwu, C., Essen, N., 2008. Complications of chronic use of skin lightening cosmetics. International Journal of Dermatology. 47, 344-353.

Palgrave, K.C.P., Palgrave, M.C.P., 2002. Trees of Southern Africa, $3^{\text {rd }}$ Edition. Struik Publishers, Cape Town, p 738 .

Pooley, E., 1993. The Complete Guide to Trees of Natal, Zululand and Transkei. Natal Flora Publications Trust, Durban, p 322.

Samuelsson, G., Farah, M.H., Claeson, P., Hagos, M., Thulin, M., Hedberg, O., Warfa, A.M., Hassan, A.O., Elim, H.H., Abdurahman, A.D., Elmi, A.S., Adbi, Y.A., Alin, M.H., 1992. Inventory of plants used in traditional medicine in Somalia. II. Plants of the families Combretaceae to Labiatae. Journal of Ethnopharmacology 37, 47-70. 
Sanz, M.J., Ferrandiz, M.L., Cejudo, M., Carmen Terencio, M., Gil, B., Bustos, G., Ubeda, A., Gunasegaran, R., Alcaraz, M.J., 1994. Influence of a series of natural flavonoids on free radical generating systems and oxidative stress. Xenobiotica 24, 689-699.

Sheth V.M., Pandya A.G., 2011. Melasma: A comprehensive update: Part II. Journal of the American Academy of Dermatology 65, 699-714.

Smit, N., Vicanova, J., Pavel, S., 2009. The hunt for natural skin whitening agents. International Journal Of Molecular Sciences 10, 5326-5349.

Sordat-Diserens, I., Rogers, C.B., Sordat, B., Hostettmann, K., 1992a. Prenylated xanthones from Garcinia livingstonei. Phytochemistry 31, 313-316.

Sordat-Diserens, I., Hamburger, M., Rogers, C.B., Hostettmann, K., 1992b. Dimeric xanthones from Garcinia livingstonei. Phytochemistry 31, 3589-3593.

Takiwaki, H., Miyaoka, Y., Arase, S. 2004. Analysis of the absorbance spectra of skin lesions as a helpful tool for detection of major pathophysiological changes. Skin Research \& Technology 10, 130-135.

Verdi, L.G., Pizzolatti, M.G., Montanher, A.B.P., Brighente, I.M.C., Smania Junior, A., Smania, E. da F.A., Simionatto, E.L., Delle Monache, F., 2004. Antibacterial and brine shrimp lethality tests of biflavonoids and derivatives of Rheedia gardneriana. Fitoterapia 75, 360-363.

Voutquenne, C., Lavaud, C., Massiot, G., Sevenet, T., Hadi, H.A., 1999. Cytotoxic polyisoprenes and glycosides of long-chain fatty alcohols from Dimocarpus fumatus. Phytochemistry 50, 63-69.

Williams, R.B., Hoch, J., Glass, T.E., Evans, R., Miller, J.S., Wisse, J.H., Kingston, D.G.I., 2003. A novel cytotoxic guttiferone analogue from Garcinia macrophylla from the Surinam rainforest. Planta Medica 69, 864-866.

Wu, Q-L., Wang, S-P., Du, L-J., Yang, J-S., Xiao, P.-G., 1998. Xanthones from Hypericum japonicum and $H$. henryi. Phytochemistry 49, 1395-1402.

Yu, G.D., 1982. Medicinal plants used for abortion and child birth in Eastern Africa. Zhong Yao Tong Bao 7, 6-7. NAPRALERT Reference T08010, Chem Abs Accession Number 1983:077349. 


\section{Figure Legends}

Figure 1: Structures of compounds isolated from Garcinia livingstonei.

Figure 2: The classical pro-oxidant hydroquinone decreases melanin content but is highly toxic to MeWo cells. MeWo melanoma cells were exposed to 25-200 $\mu \mathrm{M}$ hydroquinone or vehicle for 48 hours. Following exposure, cell death was then measured by LDH assay, normalized to vehicle and TX100-treated cells, and melanin content by absorbance at $405 \mathrm{nM}$. Each data point represents $\mathrm{n}=3$ $\pm \mathrm{SEM}$, and is representative of at least three independent experiments.

Figure 3: Response of MeWo cells to $25 \mu \mathrm{M}$ (pure compounds) and $100 \mathrm{mg} / \mathrm{mL}$ (extracts) from Garcinia livingstonei. MeWo melanoma cells were exposed to $25 \mu \mathrm{M}$ pure compounds, $100 \mathrm{mg} / \mathrm{mL}$ mixed extracts or vehicle for 48 hours. Following exposure, cell death was then measured by LDH assay, normalized to vehicle and TX100-treated cells, and melanin content by absorbance at $405 \mathrm{nM}$. $\mathrm{HQ}=$ hydroquinone, $\mathrm{Mel}=$ morelloflavone (1), Mel-7-SO $\mathrm{S}_{4}$ morelloflavone-7"-sulphate (2), Sargao = sargaol (4), Gutti A = guttiferone A (3), Ext 39b and Ext 39c = ethyl acetate and methanol extracts of G. livingstonei stem bark, respectively, Fruit peel = fruit peel (methanolic) ethyl acetate extract. Data are representative of at least three independent experiments.

Figure 4: Response of MeWo cells to Morelloflavone, Morelloflavone-7-sulphate and Sargaol from Garcinia livingstonei. MeWo melanoma cells were exposed to 1-100 $\mu \mathrm{M}$ of morelloflavone (A), morelloflavone-7-sulphate (B), sargaol (C) or vehicle for 48 hours. Following exposure, cell death was then measured by LDH assay, normalized to vehicle and TX100-treated cells, and melanin content by absorbance at $405 \mathrm{nM}$. Each data point represents $\mathrm{n}=3 \pm \mathrm{SEM}$, and is representative of at least three independent experiments. 
<smiles>[R]c1cc(O)c2c(=O)cc(-c3ccc(O)c(O)c3)oc2c1C1C(=O)c2c(O)cc(O)cc2O[C@H]1c1ccc(O)c(O)c1</smiles>

1. Morelloflavone $\mathrm{R}=\mathrm{H}$

2. Morelloflavone-7"-sulphate $\mathrm{R}=\mathrm{SO}_{3} \mathrm{H}$<smiles>CC(C)=CCC/C(C)=C/CC/C(C)=C/CC[C@]1(C)C=Cc2cc(O)cc(C)c2O1</smiles>

4. Sargaol<smiles>CC(C)=CCC[C@@]1(C)C(=O)[C@]2(CC=C(C)C)C(=O)[C@](CC=C(C)C)(C[C@@H]1CC=C(C)C)C(=O)C(C(=O)c1ccc(O)c(O)c1)=C2O</smiles>

3. Guttiferone A<smiles>[R]c1ccc2c(=O)c3c(O)cc4c(c3oc2c1O)C=CC(C)(C)O4</smiles>

5. Isojacareubin $\mathrm{R}=\mathrm{OH}$

6. 6-Deoxyisojacareubin $\mathrm{R}=\mathrm{H}$

Figure 1: Structures of compounds isolated from Garcinia livingstonei. 

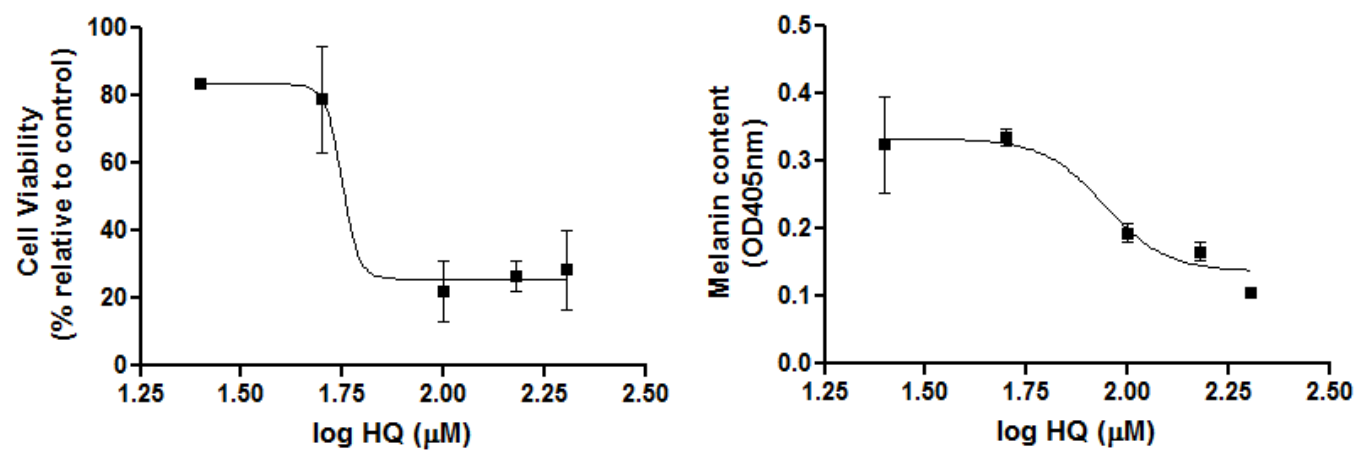

Figure 2: The classical pro-oxidant hydroquinone decreases melanin content but is highly toxic to MeWo cells. MeWo melanoma cells were exposed to 25-200 $\mu \mathrm{M}$ hydroquinone or vehicle for 48 hours. Following exposure, cell death was then measured by LDH assay, normalized to vehicle and TX100-treated cells, and melanin content by absorbance at $405 \mathrm{nM}$. Each data point represents $\mathrm{n}=3$ \pm SEM, and is representative of at least three independent experiments. 
$A$

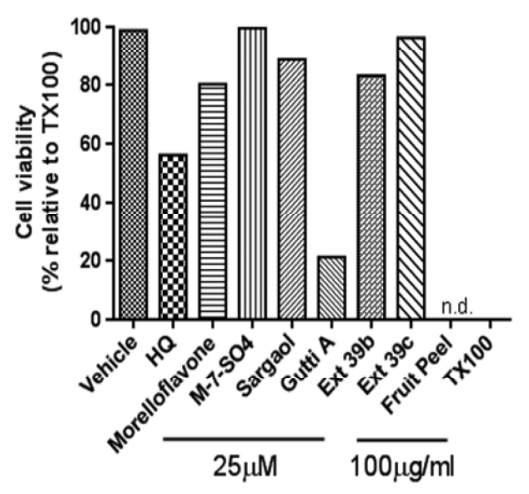

B

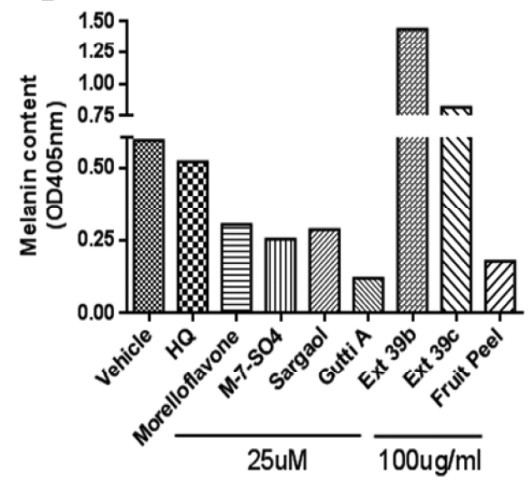

Figure 3: Response of MeWo cells to $25 \mu \mathrm{M}$ (pure compounds) and $100 \mathrm{mg} / \mathrm{mL}$ (extracts) from Garcinia livingstonei. MeWo melanoma cells were exposed to $25 \mu \mathrm{M}$ pure compounds, $100 \mathrm{mg} / \mathrm{mL}$ mixed extracts or vehicle for 48 hours. Following exposure, cell death was then measured by LDH assay, normalized to vehicle and TX100-treated cells, and melanin content by absorbance at $405 \mathrm{nM}$. $\mathrm{HQ}=$ hydroquinone, $\mathrm{Mel}=$ morelloflavone 6, Mel-7- $\mathrm{SO}_{4}=$ morelloflavone-7"'-sulphate 7, Sargao = sargaol 10, Gutti A = guttiferone A 4, Ext 39b and Ext 39c = ethyl acetate and methanol extracts of G. livingstonei stem bark, respectively, Fruit peel = fruit peel (methanolic) ethyl acetate extract. Data are representative of at three independent experiments. 
A

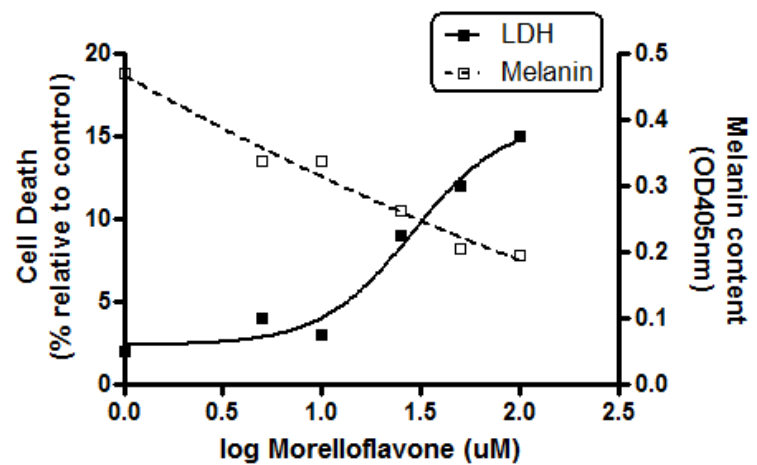

B

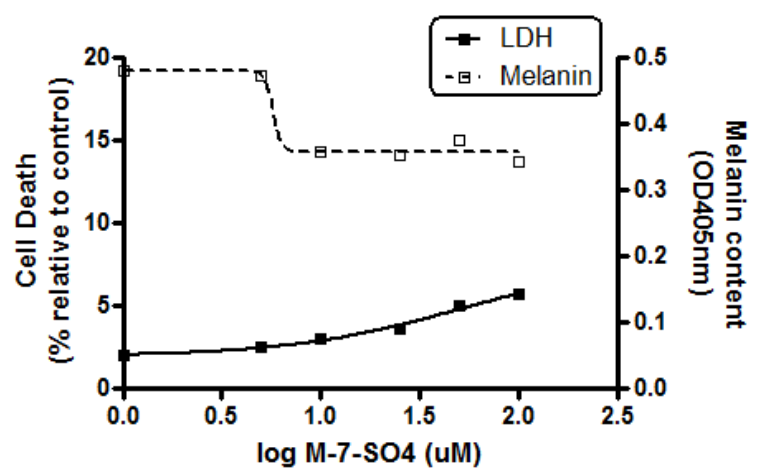

C

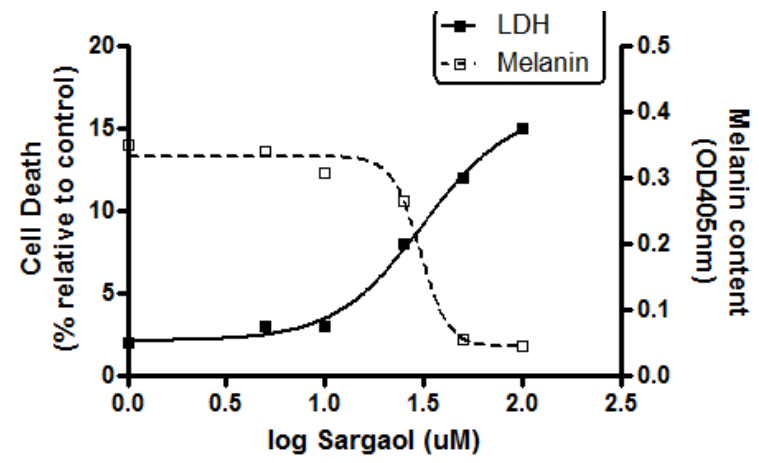

Figure 4: Response of MeWo cells to Morelloflavone, Morelloflavone-7-sulphate and Sargaol

from Garcinia livingstonei. MeWo melanoma cells were exposed to 1-100 $\mu \mathrm{M}$ of morelloflavone (A), morelloflavone-7-sulphate (B), sargaol (C) or vehicle for 48 hours. Following exposure, cell death was then measured by LDH assay, normalized to vehicle and TX100-treated cells, and melanin content by absorbance at $405 \mathrm{nM}$. Each data point represents $\mathrm{n}=3 \pm \mathrm{SEM}$, and is representative of at least three independent experiments. 